This is an electronic reprint of the original article.

This reprint may differ from the original in pagination and typographic detail.

Author(s): $\quad$ Kramar, Vadim

Title: $\quad$ UAS (drone) in Response to Coronavirus

Year: $\quad 2020$

Version: $\quad$ As published

Please cite the original version:

Kramar, V. (2020). UAS (drone) in Response to Coronavirus. In S. Balandin, V. Turchet, T. Tuytina (Eds.), Proceedings of the FRUCT'27, Trento, Italy, 79 September 2020 (pp. 90-100). Helsinki: FRUCT.

Retrieved September 24, 2020, from https://fruct.org/publications/fruct27/files/Kra.pdf 


\title{
UAS (drone) in Response to Coronavirus
}

\author{
Vadim Kramar \\ Oulu University of Applied Sciences \\ Oulu, Finland \\ Vadim.Kramar@oamk.fi
}

\begin{abstract}
This paper presents the result of an investigation how Unmanned Aviation Systems were applied in the first half of 2020 in response to the coronavirus COVID-19 challenges. The application cases collected and referenced in this paper are pandemic specific only even though many of them may be considered as typical. An important discovery was that the majority of limitations preventing the high spread of UAS applications are not technological. Nevertheless, innovative technologies, application cases and services that have originated during the pandemic period are expected to evolve and adapt to other situations and shape the future markets.
\end{abstract}

\section{INTRODUCTION}

The presented work expands the earlier-published [1] and [2] overview of technical and operational challenges associated with Unmanned Aerial Systems (UAS) operations in the Arctic with a special focus dedicated to applications of UAS in response to the coronavirus COVID-19 challenges.

It has been observed [3] that coronavirus pandemic accelerates digital transformation. Due to such of their properties as remote and autonomous operations, unmanned systems were essentially utilised in the state of the pandemic [4] where among the most important actions were isolation, contact monitoring, public distancing, and contact and community quarantines [5], [6].

A high role of robotics including autonomous UAS or ground vehicles in managing public health has been observed during the COVID-19 outbreak [7]. To facilitate the applications of unmanned systems, a great variety of Internet of Things (IoT) and Artificial Intelligence (AI) technologies and the supporting network infrastructures, including $5 \mathrm{G}$ communications were considered [6], [8], [9].

Achieving the urgent integration of UAS applications into the existing business and public processes have not been easy. For example, in China even though many applications of unmanned aerial and ground systems have had a place, those were situational applications that have not been systematically integrated [10]. In India, the Integrated Command and Control Centre was proposed to drive four initiatives within the smart city content [11]. Those initiatives are: Testing and quarantine; Containment; Health advisory; and Essential services for citizens. Even though UAS were not used in all those initiatives, several application scenarios could have been developed for any of those.

At the very beginning of the COVID-19 pandemic, it has already been observed that UAS technology is ready to be turned into a mass service [12]. That observation has been supported by dozens of pilot cases and commercial implementations only in the US, and much more all around the world. Many of those were launched even before the COVID19 outbreak.

The rest of this paper has the following structure. Overview of the methodology is given in Section II. A collection of cases categorised into application areas is presented in Section III. Discovered so far limitations and benefits of applications of UAS during the pandemic period are presented in section IV. Concluding remarks are given in Section V.

\section{Methodology}

The objective of the work is to understand how UAS have been used in response to coronavirus COVID-19 challenges. The work has been performed as such a form of qualitative research as a literature review within constructivist grounded theory methodology [13].

Over a thousand of online media articles were collected during the period from February 2020 to mid-June 2020 using news engine crawlers and RSS tools. Those articles have been analysed to reduce redundancy and exclude generic ones that do not contain concrete evidence of application of UAS in general and Unmanned Aircraft (UA), often referred as drones, in particular, or are not directly relevant to coronavirus challenges.

During the mentioned period only nine peer-reviewed and several non-peer-reviewed editorials and journal-level publications relevant to the objective of this work were found using available search engines, including Scopus, IEEE Xplore, Google Scholar, Elsevier and ResearchGate tools.

The collected from information sources cases were categorised into twenty-one categories standing for application areas. Quite a few information sources described cases that are belonging to several categories.

\section{UAS APPLICATION AREAS}

\section{A. Authority/Law Enforcement}

UAS missions for authority and law enforcement is one of the traditional application areas that includes variety of scenarios relevant to first responders, recovery from disasters, special force operations, public interactions, and many others. The missions may be performed simultaneously or 
independently by competent authorities or volunteers along with many other applications, including search and rescue, crowd tracking and surveillance, monitoring and observation, and supplemented with delivery of personal protection and medical supply, and remote measurement. [14], [15], [16], [17], [18], [19], [20], [21], [22], [23], [24], [25], [26], [27], [28], [29], [30], [31], [32], [33], [34], [35], [36], [37], [38], [39], [40], [41], [42], [43], [44].

In some countries, exemptions from existing regulations were announced to make easier applications of UAS against the coronavirus challenges [45], [46].

Nevertheless, there were cases that authority and law enforcement actions received negative perception and were restricted [47], [48], [49], [50], [51], while some authorities refused to restrict the applications of UAS [52].

\section{B. Broadcasting Information Messages}

Broadcasting information messages and public announcements to the crowds of people and conducting dedicated communication with individuals using UAS appeared to be one of the very important UAS missions during the pandemic period given the communication limitations especially in areas where other communication means are not available and due to the demand for minimising of human interactions.

The missions may be performed simultaneously with authority/law enforcement actions, crowd tracking and surveillance, monitoring and observation, and supplemented with the delivery of personal protection and medical supply, and remote measurement. Broadcasting the messages may be performed by competent authorities or even by volunteers or individuals and oriented to a group of people or individuals who breaks the quarantine rules. The messages may be transferred using the built-in UA speakers, beepers or sirens [14], [17],[19], [20], [21], [29], [31], [33], [36], [37], [40], [41], [44], [50], [53], [54], [55], [56].

\section{Cleaning}

Applications of UAS for cleaning have been considered earlier but obtained a special meaning during the COVID-19 pandemic. Drones designed for agriculture or cleaning purposes were used to spray cleaning detergents to open-air public places [57], [58], [59], [60] and sports halls [61].

\section{Communications}

Because of great mobility properties and ability to reach higher altitudes and difficult to reach by other means areas, UAS have been considered to be a good tool for establishing back-up or emergency communications e.g. using cellular networks or other means of wireless communications, deployment optimisation and slicing [62]. One of such scenarios has been described earlier with relevance to the emergency [157].

An interesting case was found about using drones to retransmit medical data from the nursing station to remote servers in a rural area where communications were not stable
[63]. UAS-enabled Long Range (LoRa) network was proposed to facilitate the possible shortage of communications [64].

\section{E. Crowd Tracking and Surveillance}

Crowd tracking and surveillance is one of the important applications of UAS that contributes to the social distancing or help to collect critical operating data. The missions may be performed simultaneously with authority/law enforcement actions by competent authorities or volunteers, broadcasting information messages, delivery of personal protection and medical supply, and remote measurement. On-site monitoring and observation of certain areas may help to discover a need for crowd tracking and surveillance, while visual evidence and situation awareness may help with collecting historical data and post-observations. [16], [17], [18], [19], [21], [23], [27], [30], [31], [32], [33], [34], [35], [45], [37], [48], [39], [41], [42], [43], [47], [46], [55], [51], [65], [66], [67], [52].

Additionally, UAS may help to create 3D maps to visualise the results of surveillance [68] or perform person recognition at the same time [69].

\section{F. Delivery: Commerce}

Delivery has been considered as one of the primary applications of UAS. This particular application area does not include delivery of medical supply, medical tests, personal protection means, pharmacy items and printed materials that are described in the following subsections. Delivery of all the other objects, including retail items, parcels, grocery, cooked food and other supply is included into this application area. [42], [47], [55], [50], [57], [67], [70], [71], [72], [73], [74], [75], [76], [77], [78], [79], [80], [81], [82], [83], [84], [85], [86], [87], [88].

Among the unusual UAS-based delivery cases during the COVID-19 pandemic, are delivery between the port and the ship [89], delivery by a small local bakery [90], delivery of new car keys [91], free beer delivery from a local pub [92].

Even in a pre-pandemic time the Drone Delivery: Benefits and Challenges report has indicated that more 36 online shoppers would be more likely to purchase and item if it would be delivered by UA [93].

\section{G. Delivery: Medical Supply}

Medical supply delivery by UAS is a special application area due to a specific nature of the delivery objects. Medical equipment, tools and medicines undergo certification and usually are subjects of more strict and specific regulations than general-purpose items available from retailers including pharmacies that typically sell medical and general-purpose items. Certain medicines require extra protection (e.g. drugs), or storage conditions (e.g. vaccines). Certain medical equipment is intended for professional use only and therefore is not available for sale (e.g. defibrillators).

All those considerations bring extra requirements and therefore challenges to the delivery process. A distinct property of this application area that the object of delivery by UAS is the one that requires involvement of health care 
professional at any stage of the provisioning process. Therefore, prescribed medicines and professional medical tools and equipment is belonging to this application area. Delivery of the such life-supporting means may be performed e.g. in case of emergency, to residential or remote areas or to motorways where traffic is blocked. [19], [32], [46], [50], [67], [75], [76], [77], [79], [80], [81], [84], [88], [94], [95], [96], [97], [98], [99], [100], [101], [102], [103], [104], [105], [106], [107], [108], [109], [110], [111].

A very short report about the experimental observations about the delivery of Automated External Defibrillator and personal protective masks in the era of COVID-19 is available [112]. The results state: "We further suggest the introduction of drones wherever may be indicated. Aside from providing AED and CPR advice to bystanders, drones can deliver PPE and communicate safety instructions." [112].

A very interesting set of experiments with delivering critical medical and other supplies to quarantined rural areas under the pandemic conditions was conducted in the USA. The results are presented in Operation Last-Mile: Critical Drone Delivery Testing report by DroneUp [82]. The experiments focused on the so-called last-mile delivery and evaluated all the relevant technological and organisational considerations. The results proved that "commercial drones can be used to deliver critical supplies over distances of less than a mile by Part 107 pilots not specifically trained in these types of operations prior to being called into service" [82].

\section{H. Delivery: Medical Tests}

In addition to traditional applications of UAS such as delivering of medical tests between hospitals, laboratories or the hospital buildings, new scenarios appeared conditioned by requirements for isolation and quarantines. [32], [57], [70], [82], [99], [113], [114], [115], [116], [117], [118], [119], [120], [121], [122],

An online survey performed in West Java and Jakarta takes a very first step towards the systematic approach with relevance to the delivery of medicines and blood samples during the COVID-19 [123]. This kind of approach considers the integration of UAS into the hospital systems. Still, a lot must be done to achieve such integration.

\section{Delivery: Personal Protection Means}

Similar to just-in-time delivery that has been listed among other services that UAS may provide [157], a range of pandemic-specific scenarios appeared. [19], [37], [70], [97], [114], [124], [125], [112].

Among the very interesting cases are delivery of protective masks by hydrogen-powered UA [126], and by high-speed fixed-wing UA that drops the delivery packages "on the fly" and those lend using parachutes [127].

\section{J. Delivery: Pharmacy Items}

Medicine that may be purchased from pharmacies without a prescription, medical tools and equipment that may be used by non-professional users and that typically may be found in pharmacies. Legislation defining requirements for medical certification, prescription and usage policies of such objects may vary from country to country. Delivery by UAS of those objects that are certified for medical purpose, but do not require the involvement of medical professional at any stage of the supply chain, is belonging to this application area. Once the medical professional is involved at any stage of provisioning, that is the subject of delivery of medical supply. All the other delivery objects for a general non-medical purpose that do not require medical certification, are belonging to commerce delivery application area. [70], [77], [82], [128].

\section{K. Delivery: Printed Materials}

Only two cases of delivery of printed materials with the help of UAS were discovered during the COVID-19 pandemic. Since both of those cases are very specific and therefore may not be categorised as belonging to other application areas, they form a new application area. Those two cases are handing over certificates at drive-in graduation ceremony [129] and delivery of public library books [130].

\section{Disinfection}

Application of UAS for disinfection became to be one of the most discussed. Disinfection is different from cleaning as the process intends to neutralise the virus elements. Even though it has not been confirmed that disinfection strongly reduces the spread of coronavirus and there were refusal cases, e.g. [131], UAS systems are efficiently used around the world to spread disinfect to those areas that are difficult to reach by other means. [14], [42], [55], [57], [60], [61], [132], [133], [134], [135], [136], [137], [138], [139],

Among the interesting cases are indoor disinfections such as one of Broadway theatre [140], hospitals [141], such large facilities as sports halls [142]. UAS for disinfection may include a thermal sensor and allow remote reading [143].

Meanwhile, it was found that spreading the disinfecting liquid is not the only way to neutralise the virus. The effect may be achieved by using C-band Ultra-Violet (UVC) lights [144], [145], [146], [147], [148].

While working on a mathematical model of coronavirus COVID-19 surface spread, the authors evaluated the model with UAS [149]. Even though the perfect treatment had not been developed at the time of evaluation, the disinfection using UA had been considered to be effective and UA had been recognised as more advantageous due to the accessibility allowing them to process difficult to reach manually areas.

Multi-functional UAS having the appropriate equipment and being able to perform simultaneously several tasks including crowd tracking and surveillance, broadcasting information messages, medical supply delivery, remote measurements and disinfection, were considered [6].

\section{Entertainment}

Applications of UAS for entertainment during the pandemic might sound strange. Nevertheless, requirements for isolation and quarantines brought a wave of innovative entertaining actions utilising a great variety of entertaining means. By not been and exclusion, UAS continues to be one of 
the remote entertaining means. UAS show using swarms of drones in one of the traditional applications of UAS that received a new boost during the pandemic [150], [151].

A voluntary initiative gathered a great number of UAS-best recorded footages from all around the world for entertaining purposes[152].

The New London Drone Orchestra that uses UAS as performance elements, released is the first album, called "Isolation/Collaboration" [153].

\section{N. Monitoring and Observation}

Monitoring and observation have always been considered to be among the primary applications of UAS. By being often combined with UAS missions for authority/law enforcement, search and rescue, crowd tracking and surveillance, visual evidence, situation awareness and remote measurements this application area continued to be among the most important. [17], [25], [27], [31], [33], [34], [35], [37], [38], [39], [41], [42], [43], [55], [95], [154], [155], [156].

\section{O. Personal Companion and Assistant}

Even though there was not observed a significant breakthrough towards personal assistive and service UAS in a form they had been described earlier [157], some interesting cases that have not been observed before appeared during the COVID-19 outbreak. For example, the results of the study [158] state that UA is a good jogging companion.

UAS may help to walk a dog without braking quarantine rules [159], [160]. This application case appeared to be so promising that IBM patented drone as a pet sitter [161].

\section{P. Remote Measurements}

Remote measurements are considered to be typical applications of UAS, such as photogrammetry or estimating the crowd size. Specific to coronavirus COVID-19 pandemic scenarios though, remote measurements started to contribute to remote diagnostics. The remote measurements missions may be performed simultaneously with authority/law enforcement actions by competent authorities or volunteers, crowd tracking and surveillance, monitoring and observation, and supplemented with the delivery of personal protection and medical supply. [27], [30], [37], [55], [143], [156], [162], [163], [164], [165], [166], [167], [168].

Remote screening with help of infrared camera to detect a higher temperature of an individual or several people at a time and therefore assume the availability of coronavirus-provoke injuries became to be a typical case of remote measurements [37]. The more advanced technologies combine multispectral imaging, computer vision and AI to detect heart rates and abnormal respiration patterns such as sneezing and coughing. [26], [28], [29], [169],

Another specific case is detection protective masks on faces of people [18], a traditional face recognition [21] or even more complicated person recognitions [69].
The IoT-based system applying UAS for coronavirus detection was proposed [170]. The key elements of the screening process are integrated thermal camera and real-time monitoring.

\section{Q. Replacing Human Labour: Agriculture}

The agriculture sector exposed a very high demand for replacing human labour with UAS during the pandemic. [171], [172], [173].

\section{R. Replacing Human Labour: Construction}

The construction sector traditionally widely uses UAS to assist and replace human labour. The pandemic requirements relevant to social distancing brought additional challenges to this application area. [174], [175], [176], [177], [178].

\section{S. Replacing Human Labour: Inventory}

Applications of UAS indoor for inventory started yet before the COVID-19 outbreak. Here as well, the pandemic requirements relevant to social distancing have brought a higher demand for replacing the human labour with UAS. [179], [180].

\section{T. Search and Rescue}

Search and rescue are among the traditional application area for UAS. For example, the community used UAS for ocean rescues and to monitor fires [95], More specific to COVID-19 pandemic, an interesting case was discovered where UAS helped to locate a missing child [181]. The entire search and rescue operation was quite challenging due to pandemic restrictions.

\section{U. Visual Evidence, Situation Awareness}

The visual evidence and situation awareness is the application area supplementary to many other, such as authority/law enforcement, crowd tracking and surveillance, monitoring and observation, search and rescue, delivery and replacing the human labour application areas.

The particularity of this application area is that while the specific to this area action may be performed as a part of UAS activity dedicated to other mission, it may also be performed by UAS missions dedicated to this application area to collect historical data, clarifying the situation, post-event observation, etc. The missions may be accomplished by volunteers or in a spontaneous way by the individuals that are not engaged with any planned operational processes or those that are the result of the planned responses. The obtained with UAS footage may be used by competent authorities as well as become available for general public [27], [152], [182], [183], [184], [185], [186].

\section{UAS APPLICATIONS - LIMITATIONS AND BENEFITS}

\section{A. Limitations}

Regulations are often mentioned as the biggest barrier for a widespread of UAS-based applications and services. Typically, regulations lag well behind the technology 
development [12] and it is unclear whether it would ever be possible to recognise, consider and regulate those challenges that are yet to identify.

Regulatory restrictions are often mentioned as a limiting factor for UAS operations Beyond Visual Line of Sight (BVLoS). Nevertheless, relevant technological limitations also exist. The never-ending compromise between payload, operational range (in its turn conditioned by engine and fuel type limitations) and aerodynamic qualities are intensified by weather conditions and rural area particularities that may include absence or inappropriate performance of supporting infrastructure.

While the absolute majority of UAS missions at these days are performed in a way that UA is remotely controlled, lack of qualified Unmanned Aircraft System operators (UAS operators), commonly known as drone operators or pilots, was mentioned several times.

Human perception and acceptance of UAS missions were mentioned as one of the very strong limitations. Generally, people understand that the application of UAS to facilitate public health actions or to save someone's life are vital. Nevertheless, visual and audial pollutions associated with UAS missions and notedly authority/law enforcement, crowd tracking and surveillance and broadcasting information messages missions were sometimes not positively accepted, especially among the rule-breakers not paying attention to social distancing or quarantine rules.

Limited deployment or absence of opportunity to have the deployment at all for testing the viability of UAS applications or services was experienced. In some countries authorities at any level were and still are too busy to consider UAS technologies as something able to significantly address the coronavirus challenges. In some cases, the supporting infrastructure was not mature enough or has not performed as required to facilitate the deployment of the application or service.

Often appeared absence of integration into the supply chain, business, and operational processes, and inability to achieve such integration is a very serious limitation. Sometimes even the most excellent technology may be useless if it is not considered to be a part of something big and not able to interoperate with that big.

Out of listed earlier [1], [2] technological and operational challenges, several were mentioned mostly relevant to the reliability, safety, security, operational range and payload.

Most of the mentioned technological challenges were relevant to the implementation of application case (e.g. making a container to satisfy the transportation conditions, achieving a better sensor performance or improving the data interpretation) and the absence of supporting infrastructure or challenges associated with interoperability or integration with the supporting infrastructure. Integration challenges were often considered to be rather organisational than technological.

An interesting approach towards the listed limitations was taken by the Civil Aviation Authority in the United Kingdom. They issued a document (CAP 1915 [46]) that supplements the existing regulations by providing guidance "as to how operations in support of the COVID-19 response may be conducted following those regulations, and the associated policy". The document describes the range of technical and operational requirements and describes the specific characteristics for simple BVLoS operations.

\section{B. Benefits}

Minimising human interactions is an important benefit that autonomous and remotely controlled systems such as UAS may bring and that has emphasised many times.

Speed of operations in certain tasks is another oftenmentioned benefit. For example, delivery using over-the-air shortcut paths or spraying a disinfect over a certain area is often faster than those operations performed by traditional ground vehicles.

The mentioned low human involvement is the conditional benefit, probably more typical to fully autonomous UAS applications. But it has been mentioned several times.

The often mentioned replacing human labour could have been considered as both, the benefit and the drawback of the UAS applications. From the point of view of the employers whose work has been replaced by UAS, such process is not desired. Still, there are many hard and dangerous work tasks that UAS could have been able to perform more efficiently and therefore could help to release human resources for those tasks that humans usually perform better.

Safe operating at distance to a subject is one of the oftenmentioned benefits. This benefit assumes the safety of the subject. For example, a delivery UA brings a package to an elderly person. Conditioned by a set of preventive actions preventing from the spread of the virus, such as automated load, preliminary disinfection of UA and delivery container and a non-stop flight, the risk of getting the coronavirus by the elderly person is significantly lower comparing to the traditional delivery process.

Remote operation safety is one of the other oftenmentioned benefits. This time, the benefit assumes safety for the UAS operator. The remote operation allows the UAS operator to stay safe even under conditions of e.g. delivery to insured people spreading the coronavirus or gathering of visual evidence at dangerous places.

UAS efficiency for certain tasks is very often mentioned as well. Those tasks from replacing the human labour and delivery application areas, and also relevant to observation, monitoring, conducting situation awareness or gathering visual evidence at e.g. difficult-to-reach areas.

The often-mentioned lower cost for certain tasks is mostly relevant to the earlier justified economic efficiency of using UAS for certain delivery tasks and efficiency of electric- or other renewable fuel-driven UAS versus those that use internal combustion engines.

Ease of use is the benefit somehow contradicting with such limitation is lack of qualified UAS operators. Nevertheless, some of the UAS applications do not require specific or 
certified category proficiency of UAS operator. The open category proficiency is generally known as hobbyist level are sufficient, e.g. for broadcasting information messages to a relative breaking the quarantine rules or gathering visual evidence for historical purposes. On the other hand, many UAS applications and services bring convenience to those to whom they are oriented, and that might be a reason for specifying such benefit.

\section{CONCLUSION}

Observing the traditional and the recently-appeared innovative application of UAS in response to the coronavirus COVID-19 pandemic challenges brings an understanding of additional requirements and challenges to be taken into consideration for designing the future UAS technology, operational principles, business and service provisioning processes, and legislation.

Since the majority of the discovered challenges are not technological, the most essential steps for the UAS community all around the world would be to discover how those limitations may be addressed and plan joint actions together with all the involved stakeholders. Joint community effort and increasing of awareness about available solutions among the decision-makers are expected to create a positive impact and therefore facilitate the rise and spread of UAS applications and services. High demand for UAS applications conditioned by pandemic requirements brings great opportunity.

The pandemic period is far not over, so it is possible to expect the higher maturity and better implementations of the observed cases, higher spread of successful ones, and appearance of new innovative applications of UAS. Any prediction is impossible, while it is possible to state that the challenges all humanity undergo now shape its future faster than one could expect. Demand-driven UAS technologies, application cases and services that received a boost or originated during this period have all the chances to shape the future markets.

\section{ACKNOWLEDGEMENT}

The author would like to thank members of Arctic Drone Labs innovation ecosystem [187] and international partners for supplying materials, giving constructive critics and focusing author's attention to interesting cases how applications of UAS (drones) responded to coronavirus COVID-19 pandemic challenges.

\section{REFERENCES}

[1] V. Kramar and H. Määttä, "UAV Arctic Challenges and the First Step: Printed Temperature Sensor," in Proceedings of the 23rd Conference of FRUCT Association, 2018, pp. 483-490.

[2] V. Kramar, "UAS (drone) Arctic Challenges - Next Steps," in Proceedings of the 25th Conference of FRUCT Association, 2019, pp. 507-514.

[3] S. Zemtsov, "New technologies, potential unemployment and 'nescience economy' during and after the 2020 economic crisis," Reg. Sci. Policy Pract., pp. 1-21, 2020, doi: 10.1111/rsp3.12286.

[4] "World Health Organisation: Coronavirus disease (COVID-19)." https://www.who.int/emergencies/diseases/novel-coronavirus-2019 (accessed Jun. 11, 2020).
[5] H. Guanche Garcell, "COVID-19. A challenge for healthcare professionals," Rev. Habanera Ciencias Medicas, vol. 19, no. 2, 2020.

[6] V. Chamola, V. Hassija, V. Gupta, and M. Guizani, "A Comprehensive Review of the COVID-19 Pandemic and the Role of IoT, Drones, AI, Blockchain and 5G in Managing its Impact," IEEE Access, vol. 8, no. May, pp. 1-1, 2020, doi: 10.1109/access.2020.2992341.

[7] G. Z. Yang et al., "Combating COVID-19-The role of robotics in managing public health and infectious diseases," Sci. Robot., vol. 5, no. 40, pp. 1-3, 2020, doi: 10.1126/scirobotics.abb5589.

[8] S. Andreev, C. Dobre, and P. Misra, "Internet of Things and Sensor Networks,” IEEE Commun. Mag., vol. 58, no. 4, p. 74, 2020, doi: 10.1109/MCOM.2020.9071994.

[9] P. Vaishnavi et al., "Artificial Intelligence and Drones to Combat COVID - 19," Preprints.org, no. June, 2020, doi: 10.20944/preprints202006.0027.v1.

[10] Z. Zeng, P.-J. Chen, and A. A. Lew, "From high-touch to high-tech: COVID-19 drives robotics adoption," Tour. Geogr., vol. 0, no. 0, pp. 1-11, 2020, doi: 10.1080/14616688.2020.1762118.

[11] “COVID-19 Indian Smart Cities: Leveraging Technology and Smart City Facilities for Rapid Response,” 2020.

[12] B. Skorup and C. Haaland, "How Drones Can Help Fight the Coronavirus," SSRN Electron. J., 2020, doi: 10.2139/ssrn.3564671.

[13] R. Ramalho, P. Adams, P. Huggard, and K. Hoare, "Literature Review and Constructivist Grounded Theory Methodology," Forum Qual. Sozialforsch. / Forum Qual. Soc. Res. Vol 16, No 3 (2015)DO 10.17169/fqs-16.3.2313, Aug. 2015.

[14] "10 Covid-busting designs: spray drones, fever helmets, anti-virus snoods | Art and design | The Guardian." https://www.theguardian.com/artanddesign/2020/mar/25/10coronavirus-covid-busting-designs (accessed Jun. 11, 2020).

[15] "Aerodyne Drones Completes 1,000 Flight Hours( Distance Around the earth) in COVID-19 OPS - sUAS News - The Business of Drones." https://www.suasnews.com/2020/05/aerodyne-dronescompletes-1000-flight-hours-distance-around-the-earth-in-covid-19ops/ (accessed Jun. 09, 2020).

[16] "Airobotics Drone Aiding Singapore Police During Coronavirus Crisis - Inside Unmanned Systems." https://insideunmannedsystems.com/airobotics-drone-aidingsingapore-police-during-coronavirus-crisis/ (accessed Jun. 13, 2020).

[17] "California police consider new uses for drones during coronavirus pandemic." https:/www.washingtonexaminer.com/news/californiapolice-consider-new-uses-for-drones-during-coronavirus-pandemic (accessed Jun. 13, 2020).

[18] "California startup aims to monitor social distancing and face masks using drones | News | $1450 \quad 99.7 \quad$ WHTC.' https://whtc.com/news/articles/2020/jun/11/california-startup-aimsto-monitor-social-distancing-and-face-masks-usingdrones $/ 1028520 /$ ?refer-section=health (accessed Jun. 13, 2020).

[19] "China adapts surveying, mapping, delivery drones to enforce world's biggest quarantine and contain coronavirus outbreak | South China Morning Post." https://www.scmp.com/business/chinabusiness/article/3064986/china-adapts-surveying-mapping-deliverydrones-task (accessed Jun. 13, 2020).

[20] "Cops Use Drones to Shame Folks Flouting Lockdown Rules Digital Trends." https://www.digitaltrends.com/news/cops-usedrones-to-shame-people-flouting-lockdown-rules/ (accessed Jun. 13, 2020).

[21] "Coronavirus could be a 'catalyst' for China to boost its mass surveillance machine, experts say." https://www.cnbc.com/2020/02/25/coronavirus-china-to-boost-masssurveillance-machine-experts-say.html (accessed Jun. 13, 2020).

[22] "Coronavirus: French police deploy drones to enforce restrictions YouTube." https://www.youtube.com/watch?v=Ts403PPfIOk (accessed Jun. 11, 2020).

[23] "Coronavirus: Italian police are monitoring lockdown with drones Business Insider." https://www.businessinsider.com/coronavirusitalian-police-monitoring-lockdown-with-drones-20203 ? $\mathrm{r}=\mathrm{US} \& \mathrm{IR}=\mathrm{T}$ (accessed Jun. 13, 2020).

[24] "Coronavirus: Multi-purpose drones monitor Mumbai's densely populated hotspots - video dailymotion." https://www.dailymotion.com/video/x7tapsq (accessed Jun. 11, 2020).

[25] "Coronavirus: UK police are using drones to 'lockdown shame' walkers - $\quad$ Business Insider." 
https://www.businessinsider.com/coronavirus-uk-police-are-usingdrones-to-lockdown-shame-walkers-2020-3? $\mathrm{r}=\mathrm{US} \& \mathrm{IR}=\mathrm{T} \quad$ (accessed Jun. 13, 2020)

[26] "Coronavirus-Spotting Drone is Being Tested in the U.S. | Digital Trends." https://www.digitaltrends.com/news/draganfly-drone-testedus/ (accessed Jun. 13, 2020)

[27] "Cyient's drone-based tech helping implement Hyderabad lockdown." https://www.siasat.com/cyients-drone-based-techhelping-implement-hyderabad-lockdown-2-1868813/ (accessed Jun. 13, 2020).

[28] 'Draganfly's 'Pandemic Drone' to begin first test flights in US DroneDJ." https://dronedj.com/2020/04/21/draganflys-pandemicdrone-begins-first-flight-us/ (accessed Jun. 09, 2020).

[29] "Drones creatively used in rural areas in battle against coronavirus Global Times." https://www.globaltimes.cn/content/1178134.shtml (accessed Jun. 11, 2020).

[30] "Drones used in effort to slow the spread of COVID-19 - CBS News." https://www.cbsnews.com/news/coronavirus-drones-slowspread-covid-19/ (accessed Jun. 11, 2020).

[31] "Drones used to prevent spread of new coronavirus in China - France 24." https://www.france24.com/en/video/20200203-drones-used-toprevent-spread-of-new-coronavirus-in-china (accessed Jun. 13, 2020).

[32] "Drones Vs. Covid-19: Ensuring Airspace Safety And Security With AI.” https://www.forbes.com/sites/amirhusain/2020/06/10/drones-vscovid-19-ensuring-airspace-safety-and-security-withai/\#14d89fe224b1 (accessed Jun. 11, 2020).

[33] "“Extreme and draconian': WA Police launch drones to enforce new two-person gathering rules." https://www.watoday.com.au/national/western-australia/extreme-anddraconian-wa-police-launch-drones-to-enforce-social-distancingrules-20200330-p54fdc.html (accessed Jun. 13, 2020).

[34] "France to use helcopters, drones to enforce virus restrictions France 24." https://www.france24.com/en/20200321-france-to-usehelcopters-drones-to-enforce-virus-restrictions (accessed Jun. 13, 2020).

[35] "CORONAVIRUS: Malaysia to use drones to control public movement."

https://www.commercialdroneprofessional.com/coronavirusmalaysia-to-use-drones-to-control-public-movement/ (accessed Jun. $13,2020)$.

[36] "New Jersey cops use speaker-drones to help enforce pandemic lockdown | Digital Trends." https://www.digitaltrends.com/cooltech/new-jersey-police-drones-tell-folks-to-stay-in-during-pandemic/ (accessed Jun. 13, 2020).

[37] "New technologies help China fight novel coronavirus epidemic People's Daily Online." http://en.people.cn/n3/2020/0214/c900009657575.html (accessed Jun. 11, 2020).

[38] "Now, drones to monitor Friday prayers at Noida mosques." https://www.outlookindia.com/newsscroll/now-drones-to-monitorfriday-prayers-at-noida-mosques/1790047 (accessed Jun. 13, 2020).

[39] "Veiligheidsregio zet drone in om te controleren of mensen voldoende afstand houden.' https://www.hartvannederland.nl/nieuws/2020/drone-controleertgenoeg-afstand/ (accessed Jun. 13, 2020).

[40] "Spain Deploys Speaker-Drones to Enforce Coronavirus Lockdown Digital Trends." https://www.digitaltrends.com/cool-tech/spaindeploys-speaker-drones-to-enforce-coronavirus-lockdown/ (accessed Jun. 13, 2020).

[41] "WA coronavirus LIVE: State's testing regime to expand as police call in drones to enforce social distancing." https://www.watoday.com.au/national/western-australia/wacoronavirus-live-wa-to-see-if-premier-adopts-two-person-rule-ascruise-debacle-escalates-20200329-p54f35.html (accessed Jun. 13, 2020).

[42] "Streets, shopping malls and playgrounds could be sprayed with disinfectant by DRONES in Australia | Daily Mail Online." https://www.dailymail.co.uk/news/article-8182293/Streets-shoppingmalls-playgrounds-sprayed-disinfectant-DRONES-Australia.html (accessed Jun. 13, 2020).

[43] "This New Coronavirus Spy Drone Will Make Sure You Stay Home." https://www.forbes.com/sites/zakdoffman/2020/03/05/meetthe-coronavirus-spy-drones-that-make-sure-you-stayhome/\#799063661669 (accessed Jun. 13, 2020).
[44] "To Enforce Coronavirus Rules, U.K. Police Use Drones, Shaming and Easter Egg Bans - The New York Times." https://www.nytimes.com/2020/04/01/world/europe/uk-policecoronavirus.html (accessed Jun. 11, 2020).

[45] "MoCA Announces Exemptions for Drones for COVID-19 Response." https://caerobotics.in/f/moca-announces-exceptions-fordrones-for-covid-19-response (accessed Jun. 13, 2020).

[46] "Unmanned Aircraft Systems BVLOS Operations in Support of the COVID-19 Response - Requirements , Guidance \& Policy," Civ. Aviat. Auth., 2020.

[47] "View: Ease regulations to make India a drone hub - The Economic Times." https:/economictimes.indiatimes.com/news/defence/viewease-regulations-to-make-india-a-dronehub/articleshow/76183866.cms (accessed Jun. 09, 2020).

[48] "Police 'pandemic drone' stirs citizen protest - DroneDJ." https://dronedj.com/2020/04/23/police-pandemic-drone-stirs-citizenprotest/ (accessed Jun. 09, 2020)

[49] "Police May Not Use Drones To Enforce Coronavirus-Related Restrictions - Coronavirus (COVID-19) - France." https:/www.mondaq.com/france/operational-impacts-andstrategy/946556/police-may-not-use-drones-to-enforce-coronavirusrelated-restrictions (accessed Jun. 09, 2020).

[50] "FAA highlights waivers that can help during COVID-19 pandemic Association for Unmanned Vehicle Systems International." https://www.auvsi.org/faa-highlights-waivers-can-help-during-covid19-pandemic (accessed Jun. 13, 2020).

[51] "Apps, drones and the far right in COVID-19.' https://phys.org/news/2020-06-apps-drones-covid-.html (accessed Jun. 11, 2020).

[52] "Surveillance Drones: French Judge Refuses to Ban Drones in Paris for Monitoring Social Distancing - DRONELIFE." https://dronelife.com/2020/05/07/surveillance-drones-french-judgerefuses-to-ban-drones-in-paris-monitoring-social-distancing/ (accessed Jun. 09, 2020).

[53] "China's massive security state is being used to crack down on the Wuhan virus - CNN." https://edition.cnn.com/2020/02/10/asia/chinasecurity-police-wuhan-virus-intl-hnk/index.html (accessed Jun. 13, 2020).

[54] "Drones to alert Ahmedabad cops with beeps | Ahmedabad News Times of India.' https://timesofindia.indiatimes.com/city/ahmedabad/drones-to-alertcops-with-beeps/articleshow/74957734.cms (accessed Jun. 13, 2020).

[55] "UAE to emerge as world leader in using drones, predicts Falcon Eye." https://www.commercialdroneprofessional.com/uae-to-emergeas-world-leader-in-using-drones-predicts-falcon-eye/ (accessed Jun. $13,2020)$.

[56] “(20) Global Times on Twitter: 'Walking around without a protective face mask? Well, you can't avoid these sharp-tongued drones! Many village and cities in China are using drones equipped with speakers to patrol during the \#coronavirus outbreak. https://t.co/ILbLmlkL9R' Twitter."

https://twitter.com/globaltimesnews/status/122321897757007872 (accessed Jun. 11, 2020).

[57] "3 ways China is using drones to fight coronavirus | World Economic Forum." https://www.weforum.org/agenda/2020/03/three-wayschina-is-using-drones-to-fight-coronavirus (accessed Jun. 11, 2020).

[58] "Coronavirus prevention: Dubai uses drones to sterilise streets." https://www.youtube.com/watch?v=eP40sS5EcLU (accessed Jun. 13, 2020).

[59] "Is coronavirus changing the world of cleaning? - BBC News." https://www.bbc.com/news/business-52703044 (accessed Jun. 09, 2020).

[60] "Coronavirus: NC company hopes its 'sanitation drones' help economy take off - ABC11 Raleigh-Durham.” https://abc11.com/coronavirus-in-nc-covid-19-sanitizing-sanitationdrones/6229215/ (accessed Jun. 09, 2020).

[61] "Drone Tech Startup EagleHawk Offering Drone-Enabled Service to Combat Covid-19 - sUAS News - The Business of Drones." https://www.suasnews.com/2020/05/drone-tech-startup-eaglehawkoffering-drone-enabled-service-to-combat-covid-19/ (accessed Jun. 09, 2020).

[62] "Securing the skies in the era of drones | VTT." https://www.vttresearch.com/en/news-and-ideas/securing-skies-eradrones (accessed Jun. 15, 2020). 
[63] "Drones could send health data | Local News | chroniclejournal.com." https://www.chroniclejournal.com/news/local/drones-could-sendhealth-data/article_c9e65a80-a489-11ea-8247-f3fee3e8154f.html (accessed Jun. 09, 2020).

[64] O. A. Saraereh, A. Alsaraira, I. Khan, and P. Uthansakul, "Performance evaluation of UAV-enabled LoRa networks for disaster management applications," Sensors (Switzerland), vol. 20, no. 8, pp. 1-18, 2020, doi: 10.3390/s20082396.

[65] "Airobotics Gets Approval to Fly Automated Commercial Drones Over Singapore - $\quad$ UAS VISION.' https://www.uasvision.com/2020/05/22/airobotics-gets-approval-tofly-automated-commercial-drones-over-singapore/ (accessed Jun. 09 , 2020).

[66] "Aerial maps enabling Social Distancing for COVID Hotspot Management." https://www.indshine.com/blog/2020-04-17-aerialmaps-enabling-social-distancing-for-covid-hotspot-management/ (accessed Jun. 11, 2020).

[67] "drones: DGCA allows Swiggy, Zomato, Dunzo to test-fly longrange drones, Technology News, ETtech.' https://tech.economictimes.indiatimes.com/news/technology/dgcaallows-swiggy-zomato-dunzo-to-test-fly-long-rangedrones/76178869?redirect=1 (accessed Jun. 09, 2020).

[68] "Coronavirus: How Drona Maps is using drones to create 3D maps of cities in India to track COVID-19 hotspots." https://yourstory.com/2020/04/coronavirus-drona-maps-drones-3dvisuals-hotspots (accessed Jun. 13, 2020).

[69] "Founded By Ex-Google Engineers, Meet The Drone Startup Scoring Millions In Government Surveillance Contracts." https://www.forbes.com/sites/thomasbrewster/2020/06/03/funded-bykevin-durant-and-founded-by-ex-googlers-this-drone-startup-isscoring-millions-in-government-surveillance-contracts/ (accessed Jun. 09, 2020).

[70] "Africa's Drone Medical Delivery Service Saves Lives in Lockdown | INSEAD Knowledge.” https://knowledge.insead.edu/blog/inseadblog/africas-drone-medical-delivery-service-saves-lives-inlockdown-14371 (accessed Jun. 13, 2020).

[71] “Alphabet's drone delivery service Wing has made 'thousands' of deliveries in Australia during the pandemic | Business Insider." https://www.businessinsider.com.au/alphabets-drone-deliveryservice-wing-has-made-thousands-of-deliveries-in-australia-duringthe-pandemic-2020-5 (accessed Jun. 09, 2020).

[72] "China fights coronavirus with delivery drones - GPS World: GPS World." https://www.gpsworld.com/china-fights-coronavirus-withdelivery-drones/ (accessed Jun. 13, 2020).

[73] "Demand for drone deliveries reaches new heights during COVID-19 - TechRepublic." https://www.techrepublic.com/article/demand-fordrone-deliveries-reaches-new-heights-during-covid-19/ (accessed Jun. 09, 2020).

[74] "Drone Delivery Services Provide Much-needed Supplies to Rural Communities." https://www.prnewswire.co.uk/news-releases/dronedelivery-services-provide-much-needed-supplies-to-ruralcommunities-824752662.html (accessed Jun. 09, 2020).

[75] "Drone flies to the rescue in first coronavirus food and drugs delivery | News | The Times." https://www.thetimes.co.uk/article/drone-fliesto-the-rescue-in-first-coronavirus-food-and-drugs-delivery3zpqbw5qx (accessed Jun. 13, 2020).

[76] "Drones to be used to deliver food and medical supplies to hospitals Metro News." https://metro.co.uk/2020/04/24/drones-used-deliverfood-medical-supplies-hospitals-12606228/ (accessed Jun. 11, 2020).

[77] "Flytrex begins backyard drone deliveries in North Dakota DroneDJ." https://dronedj.com/2020/04/24/flytrex-drone-deliveriesnorth-dakota/ (accessed Jun. 11, 2020).

[78] J. Linchant, J. Lisein, J. Semeki, P. Lejeune, and C. Vermeulen, "Are unmanned aircraft systems (UASs) the future of wildlife monitoring? A review of accomplishments and challenges," Mamm. Rev., vol. 45, no. 4, pp. 239-252, 2015, doi: 10.1111/mam.12046.

[79] "UAS Magazine - The Latest News on Unmanned Aerial Systems Italian drone dealer creates delivery box for swabs, COVID meds." http://uasmagazine.com/articles/2146/italian-drone-dealer-createsdelivery-box-for-swabs-covid-meds (accessed Jun. 11, 2020).

[80] "Drone Delivery: Irish Startup Manna Launches Food Delivery Test Bloomberg." https:/www.bloomberg.com/news/features/2020-0227/drone-delivery-irish-startup-manna-launches-food-delivery-test (accessed Jun. 09, 2020).
[81] "JD Logistics deploys autonomous shuttles, drones for last-mile deliveries in coronavirus quarantine zones | Supply Chain Dive." https://www.supplychaindive.com/news/jd-logistics-autonomousdrones-deliveries-coronavirus/571875/ (accessed Jun. 11, 2020).

[82] J. Fuller, "Last Mile Drone Delivery: Testing the Limits of Commercial Operations - DRONELIFE," 2020.

[83] "Restaurant employs drone delivery to enforce social distancing VnExpress

International." https://e.vnexpress.net/news/life/trend/restaurant-employs-dronedelivery-to-enforce-social-distancing-4072392.html (accessed Jun. $13,2020)$.

[84] "Southampton-Isle of Wight medical delivery, from the report 'Flying High: The future of drone technology in UK cities' | Nesta." https://www.nesta.org.uk/report/flying-high-challenge-future-ofdrone-technology-in-uk-cities/southampton-isle-of-wight-medicaldelivery/\#content (accessed Jun. 11, 2020).

[85] "UPS to start using drones as demand for same-day delivery increases." https://dronedj.com/2020/02/03/ups-to-start-using-dronesas-demand-for-same-day-delivery-increases/ (accessed Jun. 13, 2020).

[86] "Wing drone deliveries soar in Christiansburg during COVID-19 outbreak." https://www.wsls.com/news/local/2020/04/04/wing-dronedeliveries-soar-in-christiansburg-during-covid-19-outbreak/ (accessed Jun. 09, 2020).

[87] "Sandwiches via drone: Food delivery adapts to social distancing WISH-TV | Indianapolis News | Indiana Weather | Indiana Traffic." https://www.wishtv.com/news/local-news/sandwiches-via-dronefood-delivery-adapts-to-social-distancing/ (accessed Jun. 11, 2020).

[88] "Google's Wing drones deliver essentials during coronavirus pandemic." https://www.dezeen.com/2020/04/15/google-wing-dronedelivery-coronavirus-virginia/ (accessed Jun. 11, 2020).

[89] "Drone completes first delivery to a vessel at the Port of Rotterdam DroneDJ." https://dronedj.com/2020/06/03/drone-completes-firstdelivery-to-a-vessel-at-the-port-of-rotterdam/ (accessed Jun. 09, 2020).

[90] "A bakery owner in southeastern Turkey uses a drone to deliver bread to his costumers during the coronavirus lockdown." https://twitter.com/fatihcagrii/status/1252558855608958976?s=12 (accessed Jun. 18, 2020).

[91] "Chinese carmaker Geely will airdrop customers new car keys by drone - Business Insider." https://www.businessinsider.com/geelydrone-car-keys-coronavirus-social-distancing-covid-20203 ? international $=$ true \& $\mathrm{r}=\mathrm{US} \& \mathrm{IR}=\mathrm{T}$ (accessed Jun. 13, 2020).

[92] "Meath pub delivering free beer by drone to loyal local customers during lockdown | The Irish Post." https://www.irishpost.com/news/meath-pub-delivering-free-beerdrone-loyal-local-customers-lockdown-184546 (accessed Jun. 11, 2020).

[93] "Coronavirus and Drones: Study Says Crisis Changing Minds about Disruptive Technology https://dronelife.com/2020/06/02/coronavirus-and-drones-study-sayscrisis-changing-minds-about-disruptive-technology/ (accessed Jun. 11, 2020).

[94] "Chile: A drone delivers medicine to the elderly who are socially isolated to prevent contracting the coronavirus.' https://twitter.com/GulistanNewsIn/status/1252232953788198915 (accessed Jun. 13, 2020).

[95] "Chilean seniors look to the sky for medicine and masks - Reuters." https://uk.reuters.com/article/health-coronavirus-chile-drone/chileanseniors-look-to-the-sky-for-medicine-and-masks-idUKL1N2C817V (accessed Jun. 11, 2020).

[96] "Coronavirus: Drones to deliver NHS supplies to Isle of Wight - BBC News." https://www.bbc.com/news/technology-52419705 (accessed Jun. 11, 2020).

[97] "Coronavirus: medical drones could soon be helping to beat the crisis." https://theconversation.com/coronavirus-medical-dronescould-soon-be-helping-to-beat-the-crisis-137640 (accessed Jun. 09, 2020).

[98] "Drones get 'air corridors' to deliver medical supplies to hospitals in major expansion of unmanned flight." https://www.telegraph.co.uk/news/2020/05/04/drones-get-aircorridors-deliver-medical-supplies-hospitals/ (accessed Jun. 13, 2020).

[99] "Drones in Development: Innovating the Supply Chain to Reach Patients in Remote Areas | USAID Global Health Supply Chain 
Program." https://www.ghsupplychain.org/news/dronesdevelopment-innovating-supply-chain-reach-patients-remote-areas (accessed Jun. 11, 2020).

[100] "UPDATE: Drones to fly COVID-19 relief in parts of North Carolina

FierceElectronics." https://www.fierceelectronics.com/electronics/drones-to-fly-vovid19-relief-food-and-supplies-parts-north-carolina (accessed Jun. 11, 2020).

[101] "Report: Drones Viable Delivery Option During Health Crisis." https://www.govtech.com/products/Report-Drones-Viable-DeliveryOption-During-Health-Crisis.html (accessed Jun. 12, 2020).

[102] "Drone-to-door medicines trial takes flight in Ireland - BBC News." https://www.bbc.com/news/technology52206660?at_medium $=$ custom $7 \&$ at_custom $3=\% 40 \mathrm{BBCTech} \&$ at ca mpaign $=64 \&$ at_custom $2=$ twitter\&at_custom $4=569$ C6FD0-8AF 1 11EA-9319-4EA54744363C\&at custom $1=\% 5$ Bpost + type $\% 5 \mathrm{D}$ (accessed Jun. 11, 2020).

[103] "Medical Delivery Drones Tested in Munich - UAS VISION." https://www.uasvision.com/2020/06/10/medical-delivery-dronestested-in-munich/ (accessed Jun. 11, 2020).

[104] "Meet the drone startup keeping operations running in Africa... from its Melbourne office - SmartCompany." https:/www.smartcompany.com.au/coronavirus/swoop-aero-covid19-drones/ (accessed Jun. 11, 2020)

[105] "NHS Scotland Drone Delivery Trial Supports Covid-19 Response - DRONELIFE." https://dronelife.com/2020/05/26/nhs-scotlanddrone-delivery-trial-will-support-covid-19-response/ (accessed Jun. 09, 2020).

[106] "Skyports joins Thales in COVID-19 drone-delivery trial - GPS World: GPS World." https://www.gpsworld.com/skyports-joinsthales-in-covid-19-drone-delivery-trial/ (accessed Jun. 09, 2020).

[107] "Swoop Aero triples Malawian fleet size to support COVID-19 response - sUAS News - The Business of Drones." https://www.suasnews.com/2020/06/swoop-aero-triples-malawianfleet-size-to-support-covid-19-response/ (accessed Jun. 12, 2020).

[108] "UPS and CVS set to deliver prescription medication by drone to a Florida retirement community | Daily Mail Online." https://www.dailymail.co.uk/sciencetech/article-8261953/UPS-CVSset-deliver-prescription-medication-drone-Florida-retirementcommunity.html (accessed Jun. 11, 2020).

[109] "Wingcopter announced as one of the winners of German Government's $€ 24$ million COVID-19 hackathon - sUAS News - The Business Drones." https:/www suasnews.com/2020/05/wingcopter-announced-as-oneof-the-winners-of-german-governments-e24-million-covid-19hackathon/ (accessed Jun. 09, 2020).

[110] "Zipline and Novant Health Start Drone Operations In North Carolina - $\quad$ UAS VISION." https://www.uasvision.com/2020/05/29/zipline-and-novant-healthstart-drone-operations-in-north-carolina/ (accessed Jun. 09, 2020).

[111] "Zipline Drones Will Continuously Drop Supplies To Hospital In North

Carolina.'

https://www.forbes.com/sites/kelseyatherton/2020/05/27/drones-willcontinuously-drop-supplies-to-hospital-in-northcarolina/\#6e259cdb3183 (accessed Jun. 11, 2020).

[112] "Novant Health Launches Nation's First Emergency Drone Operation for COVID-19 Pandemic Response." https://hitconsultant.net/2020/06/08/novant-health-launches-nationsfirst-emergency-drone-operation-covid-19pandemic/\#.Xt8V0UUzYuU (accessed Jun. 09, 2020).

[113] "Coronavirus tests should be delivered to people's homes using DRONES, study suggests | Daily Mail Online." https://www.dailymail.co.uk/sciencetech/article8254327/Coronavirus-tests-delivered-peoples-homes-using DRONES-study-suggests.html (accessed Jun. 11, 2020).

[114] "Coronavirus: Drones used to deliver coronavirus tests and PPE to the Isle of Mull - Business Insider." https://www.businessinsider.com/drones-deliver-medical-suppliesisle-mull-2020-5? $\mathrm{r}=\mathrm{US} \& \mathrm{IR}=\mathrm{T}$ (accessed Jun. 11, 2020).

[115] "Drone deliveries soar in rural Scotland during coronavirus outbreak | Scotland | The Guardian." https://amp-theguardiancom.cdn.ampproject.org/c/s/amp.theguardian.com/uknews/2020/may/29/drone-deliveries-soar-in-rural-scotland-duringcoronavirus-outbreak (accessed Jun. 11, 2020).
[116] "Drone delivers Covid-19 tests to laboratory in less than seven minutes - sUAS News - The Business of Drones." https://www.suasnews.com/2020/06/drone-delivers-covid-19-tests-tolaboratory-in-less-than-seven-minutes/ (accessed Jun. 09, 2020).

[117] "First ever drone flight carrying coronavirus patient sample in Estonia | News | ERR.” https://news.err.ee/1081652/first-ever-droneflight-carrying-coronavirus-patient-sample-in-estonia (accessed Jun. $13,2020)$.

[118] "In Ghana, Drones Are Turning Out to Be a Key Tool for Transporting COVID-19 Tests." https://www.globalcitizen.org/en/content/ghana-using-drones-totransport-covid-19-tests/ (accessed Jun. 09, 2020).

[119] "Poland successfully uses a Drone to deliver coronavirus samples from one Warsaw hospital to another. - Drone eCONomy." https://africandronevoice.com/2020/05/01/poland-successfully-usesa-drone-to-deliver-coronavirus-samples-from-one-warsaw-hospitalto-another/ (accessed Jun. 11, 2020)

[120] "Quantum-Systems Trinity F90+ UAV delivers medical samples to laboratory YouTube." https://www.youtube.com/watch?v=LHp8wUb6m9M\&feature=youtu be (accessed Jun. 13, 2020)

[121] "Study says drones are best way to deliver COVID-19 tests DroneDJ." https://dronedj.com/2020/04/24/study-says-drones-arebest-way-to-deliver-covid-19-tests/ (accessed Jun. 11, 2020).

[122] "UK aid-backed drone technology supports Ghana's coronavirus fight - GOV.UK." https://www.gov.uk/government/news/uk-aidbacked-drone-technology-supports-ghanas-coronavirus-fight (accessed Jun. 09, 2020).

[123] A. A. B. Ruíz, "The Deployment of Drones in Sending Drugs and Patient Blood Samples COVID-19,” Indones. J. Sci. Technol., vol. 5 , no. 2, pp. 54-67, 2020.

[124] "Drones Will Deliver COVID-19 Supplies To Remote Beausoleil First Nation | HuffPost Canada." https://www.huffingtonpost.ca/entry/drone-covid-firstnation ca 5edea533c5b6fd8ala2912a0?guccounter=1 (accessed Jun. 09, 2020).

[125] "Coronavirus: Facemasks delivered by hydrogen-powered drone." https://www.h2-view.com/story/coronavirus-facemasks-delivered-byhydrogen-powered-drone/ (accessed Jun. 11, 2020).

[126] M. J. van Veelen, M. Kaufmann, H. Brugger, and G. Strapazzon, "Drone delivery of AED's and personal protective equipment in the era of SARS-CoV-2," Resuscitation, vol. 152, pp. 1-2, 2020, doi: 10.1016/j.resuscitation.2020.04.038.

[127] "Zipline's drones take to the sky in North Carolina - DroneDJ." https://dronedj.com/2020/05/27/ziplines-drones-take-to-the-sky-innorth-carolina/ (accessed Jun. 09, 2020).

[128] "AirBox Technologies successfully demonstrates Its AirBox Home technology in Virginia - sUAS News - The Business of Drones." https://www.suasnews.com/2020/05/airbox-technologiessuccessfully-demonstrates-its-airbox-home-technology-in-virginia/ (accessed Jun. 09, 2020).

[129] "Coronavirus: Drones to hand over certificates at drive-in graduation ceremony in Dubai | Uae - Gulf News." https://gulfnews.com/uae/coronavirus-drones-to-hand-overcertificates-at-drive-in-graduation-ceremony-in-dubai-1.71887516 (accessed Jun. 09, 2020).

[130] "Pupils to receive library books by Google-backed drone delivery.', https://www.commercialdroneprofessional.com/pupils-to-receivelibrary-books-by-google-backed-drone-delivery/ (accessed Jun. 13, 2020).

[131] "Mumbai civic body will not use drones to disinfect coronavirus containment zones - mumbai news - Hindustan Times.' https://www.hindustantimes.com/mumbai-news/mumbai-civic-bodywill-not-use-drones-to-disinfect-coronavirus-containmentzones/story-ZZjYKXx2EUpwTRTa27BXVN.html (accessed Jun. 13, 2020).

[132] "Coronavirus - Nigerian Startup Beat Drone deploys it's drones to disinfect communities - $\quad$ CNBC Africa." https://www.cnbcafrica.com/africa-pressoffice/2020/06/08/coronavirus-nigerian-startup-beat-drone-deploysits-drones-to-disinfect-communities/ (accessed Jun. 09, 2020).

[133] "Coronavirus: Indonesia uses drones to disinfect dense areas | AFP YouTube." https://www.youtube.com/watch?v=IjhN3hzgLLg (accessed Jun. 11, 2020). 
[134] "Coronavirus: Tamil Nadu startup uses drones to disinfect roads, buildings - India News." https:/www.indiatoday.in/india/story/tamilnadu-startup-drones-spray-disinfectant-chennai-coronavirus1660786-2020-03-28 (accessed Jun. 11, 2020).

[135] "Long-endurance drones prove their value against COVID-19 GPS World: GPS World." https://www.gpsworld.com/longendurance-drones-prove-their-value-against-covid-19/ (accessed Jun. $13,2020)$.

[136] "Municipal Corporation conducts sanitisation drive in Delhi's Narela area through drones." https://www.aninews.in/news/national/general-news/municipalcorporation-conducts-sanitisation-drive-in-delhis-narela-areathrough-drones20200403153022/ (accessed Jun. 13, 2020).

[137] "Syracuse company develops coronavirus-killing drone for arenas and stadiums - syracuse.com.' https://www.syracuse.com/coronavirus/2020/05/syracuse-companydevelops-coronavirus-killing-drone-for-arenas-and-stadiums.html (accessed Jun. 13, 2020).

[138] "XAG Establishes Five Million Yuan Fund for Drone Disinfection Operation to Fight Coronavirus Outbreak." https://apnews.com/PR Newswire/084d73b9bc8644301e02ef2d8e809597 (accessed Jun. 13, 2020).

[139] "First use of drones to fight coronavirus in France - YouTube." https://www.youtube.com/watch? $\mathrm{v}=$ scgmi2loSWg (accessed Jun. 13, 2020).

[140] "Company Creates Drones To Disinfect Broadway Theaters." https://www.forbes.com/sites/marchershberg/2020/05/19/companycreates-drones-to-disinfect-broadway-theaters/\#21be78dc6a38 (accessed Jun. 11, 2020).

[141] "Drone deployed to disinfect hospital in Xiamen - YouTube." https://www.youtube.com/watch?v=8LIFcIdnL_g (accessed Jun. 13, 2020).

[142] "Drone Disinfection System Kills Coronavirus In Large Indoor Spaces." https://facilityexecutive.com/2020/04/drone-disinfectionsystem-kills-coronavirus-in-large-indoor-spaces/ (accessed Jun. 11, 2020).

[143] "Fighting COVID-19 with Disinfecting Drones and Thermal Sensors $>\quad$ ENGINEERING.com." https://www.engineering.com/DesignerEdge/DesignerEdgeArticles/A rticleID/20324/Fighting-COVID-19-with-Disinfecting-Drones-andThermal-Sensors.aspx (accessed Jun. 13, 2020).

[144] "World's First Indoor Disinfection Drone Ready to Fight COVID19 | Medgadget." https://www.medgadget.com/2020/04/worlds-firstindoor-disinfection-drone-ready-to-fight-covid-19.html (accessed Jun. 13, 2020).

[145] "Coronavirus: Irish researchers develop drone that can deliver UV light to disinfect public spaces." https://www.thejournal.ie/usingdrones-to-sterilise-public-areas-from-coronavirus-5113866-Jun2020/ (accessed Jun. 09, 2020).

[146] "Irish scientists unveil UV drone to combat COVID-19." https://www.irishcentral.com/news/irish-ultra-violet-drones-covid (accessed Jun. 09, 2020).

[147] "Lenexa startup launches indoor drone that could kill Coronavirus with ultraviolet waves." https:/www.startlandnews.com/2020/04/digital-aerolus/ (accessed Jun. 13, 2020).

[148] "Scientists develop UV drone to battle Covid-19 spread." https://www.rte.ie/news/ireland/2020/0604/1145426-ultra-violetdrones-covid19-coronavirus/ (accessed Jun. 09, 2020).

[149] A. Jayaprakash and M. Kayalvizhi, "Mathematical analysis of Surface spread of COVID 19 and disinfection using Drones," GEDRAG Organ., vol. 33, no. 02, pp. 1836-1844, 2020, doi: https://www.doi.org/10.37896/GOR33.02/189.

[150] "City councilors considering 2021 Independence Day drone show Sequim Gazette." https:/www.sequimgazette.com/news/citycouncilors-considering-2021-independence-day-drone-show/ (accessed Jun. 09, 2020).

[151] "Drone light show by Verge Aero honors frontline | Pennovation Works." https://www.pennovation.upenn.edu/news/drone-light-showverge-aero-honors-frontline (accessed Jun. 13, 2020).

[152] "Coronavirus drone footage ultimate roundup: USA, China, more DroneDJ." https://dronedj.com/2020/04/01/ultimate-coronavirusdrone-footage-roundup-usa-china-italy-spain-and-more/ (accessed Jun. 13, 2020).
[153] "The Day - The New London Drone Orchestra releases its first album, 'Isolation/Collaboration' - News from southeastern Connecticut."

https://www.theday.com/article/20200604/ENT10/200609780 (accessed Jun. 09, 2020).

[154] "This Drone Software Tracks Social Distancing From the Air Digital Trends." https://www.digitaltrends.com/news/this-dronesoftware-tracks-social-distancing-from-the-air/ (accessed Jun. 15, 2020).

[155] "Drones Help Utility Companies Protect Critical Infrastructure in Times of Crisis - Inside Unmanned Systems." https://insideunmannedsystems.com/drones-help-utility-companiesprotect-critical-infrastructure-in-times-of-crisis/ (accessed Jun. 09, 2020).

[156] 'UniSA working on 'pandemic drone' to detect coronavirus News and events - University of South Australia." https://www.unisa.edu.au/Media-Centre/Releases/2020/unisaworking-on-pandemic-drone-to-detect-coronavirus (accessed Jun. 13, 2020).

[157] V. Kramar, "Smart Living - Personal and Service Drones," in Proceedings of the 23rd Conference of FRUCT Association, 2018, pp. 476-482

[158] "Drones Make Good Jogging Companions, Research Finds Popular Science." https://www.popsci.com/study-says-drones-makegood-jogging-companions/ (accessed Jun. 13, 2020).

[159] "Drone walks dog amid coronavirus lockdown in Cyprus YouTube." https:/www.youtube.com/watch?v=LxvgUBp4YPA (accessed Jun. 11, 2020).

[160] "This Dog's Walker Is a Drone - YouTube." https://www.youtube.com/watch?v=FO57bUVYFas (accessed Jun. $11,2020)$.

[161] "IBM Filed a Patent for a Drone That Acts Like a Pet-Sitter Fortune." https://fortune.com/2017/03/24/ibm-drone-patent-pet-sitter/ (accessed Jun. 13, 2020).

[162] "Colombian police use drones to detect high body temperatures Reuters." https://www.reuters.com/article/us-health-coronaviruscolombia-drones/colombian-police-use-drones-to-detect-high-bodytemperatures-idUSKBN22W2XM (accessed Jun. 13, 2020).

[163] "DJI drones to help in the containment of Covid-19 AirMed\&Rescue."

https://www.airmedandrescue.com/latest/news/dji-drones-helpcontainment-covid-19 (accessed Jun. 11, 2020).

[164] "DJI uses a cotton swab to fight against coronavirus - DroneDJ." https://dronedj.com/2020/02/26/dji-uses-a-cotton-swab-to-fightagainst-coronavirus/ (accessed Jun. 09, 2020).

[165] "Draganfly Selected to Globally Integrate Breakthrough Health Diagnosis Technology Immediately onto Autonomous Camera's and Specialized Drones to Combat Coronavirus (COVID-19) and Future Health Emergencies - 26.03.2020." https://www.wallstreetonline.de/nachricht/12332872-draganfly-selected-to-globallyintegrate-breakthrough-health-diagnosis-technology-immediatelyonto-autonomous-camera-s-and-specialized-drones-to-combatcoronavirus-covid-19-and-future-health-emergencies/all (accessed Jun. 11, 2020).

[166] "Faked Coronavirus Fever Detection, Athena Used Hikvision; Responds - Selling NDAA Compliant Cameras, Pledging 50\% Of Profits to Victims." https://ipvm.com/reports/fakedcorona?code=allow (accessed Jun. 13, 2020).

[167] "How Innovators Are Adapting Existing Technologies to Fight COVID-19 | Innovation | Smithsonian Magazine.' https:/www.smithsonianmag.com/innovation/how-innovators-areadapting-existing-technologies-fight-covid-19-180974662/ (accessed Jun. 11, 2020).

[168] "IIT alumni develops drone with infrared camera for thermal screening to identify Coronavirus suspects | Business Insider India." https://www.businessinsider.in/tech/news/iit-alumni-develop-dronewith-infrared-camera-for-thermal-screening-to-identify-coronavirussuspects/articleshow/74963342.cms (accessed Jun. 13, 2020).

[169] 'Draganfly's 'Pandemic Drone' technology Conducts Initial Flights Near New York City to Detect COVID-19 Symptoms and Identify Social Distancing Canadian Stock Exchange:DFLY.' https://www.globenewswire.com/newsrelease/2020/04/21/2019221/0/en/Draganfly-s-Pandemic-Dronetechnology-Conducts-Initial-Flights-Near-New-York-City-to-Detect- 
COVID-19-Symptoms-and-Identify-Social-Distancing.html (accessed Jun. 11, 2020).

[170] M. N. Mohammed, N. A. Hazairin, S. Al-Zubaidi, A. K. Sairah, S Mustapha, and E. Yusuf, "Toward a novel design for coronavirus detection and diagnosis system using iot based drone technology," Int. J. Psychosoc. Rehabil., vol. 24, no. 7, pp. 2287-2295, 2020, doi: 10.37200/IJPR/V24I7/PR270220.

[171] "Agricultural Robots and Drones Market To Discover Astonishing Hike Of Industry By 2026 | Top Key Vendors Like 3D Robotics, Inc., Festo AG \& Co. KG, DeLaval Inc. - 3w Market News Reports.' https://3wnews.org/uncategorised/1161040/agricultural-robots-anddrones-market-to-discover-astonishing-hike-of-industry-by-2026-topkey-vendors-like-3d-robotics-inc-festo-ag-co-kg-delaval-inc/ (accessed Jun. 13, 2020).

[172] "Drones and imported machines to be used against locusts: Tomar." https://www.devdiscourse.com/article/headlines/1076119 drones-and-imported-machines-to-be-used-against-locusts-tomar (accessed Jun. 09, 2020).

[173] "XAG Introduces Rice Seeding Drone to Mitigate Labour Shortage - sUAS News - The Business of Drones." https://www.suasnews.com/2020/06/xag-introduces-rice-seedingdrone-to-mitigate-labour-shortage/ (accessed Jun. 09, 2020).

[174] "Construction, Coronavirus, and Drones - Constructech." https://constructech.com/construction-coronavirus-and-drones/ (accessed Jun. 13, 2020).

[175] "Using Drones in Residential Construction May Become More Popular Builder Magazine.' https://www.builderonline.com/building/operations/could-drone-userise-in-residential-construction-post-covid_c (accessed Jun. 15, 2020).

[176] "Drones Have Increased Relevance to Building in a World Strained by the Coronavirus | JLC Online." https://www.jlconline.com/business/drones-have-increasedrelevance-to-building-in-a-world-strained-by-the-coronavirus_o (accessed Jun. 13, 2020).

[177] "GCC construction turns to drones in post-COVID-19 - Business Construction https://www.constructionweekonline.com/business/265222-gccconstruction-turns-to-drones-to-adapt-to-new-normal (accessed Jun. $13,2020)$.

[178] "The future of construction and AEC for a post-COVID-19 world | Equipment and IT | Construction Global.” https://www.constructionglobal.com/equipment-and-it/futureconstruction-and-aec-post-covid-19-world (accessed Jun. 13, 2020).

[179] "Drones Keeping Track of Warehouse Inventory | Exhibit City News." https://exhibitcitynews.com/drones-keeping-track-ofwarehouse-inventory/ (accessed Jun. 11, 2020).

[180] "Inventory drones strengthen Post-COVID supply chain DRONELIFE." https://dronelife.com/2020/06/12/inventory-dronesstrengthen-post-covid-supply-chain/ (accessed Jun. 12, 2020).

[181] "Search-and-rescue Drones Help Locate Missing Child." https://dronelife.com/2020/04/29/search-and-rescue-drones-missingchild/ (accessed Jun. 11, 2020).

[182] "Coronavirus: Drone Footage of San Francisco's Empty Streets YouTube." https://www.youtube.com/watch?v=yQky8qARcwc (accessed Jun. 11, 2020).

[183] "Drone footage captures the eerie, deserted streets of Wuhan, China - - YouTube,' https://www.youtube.com/watch?v=RMYQjqiCSHM (accessed Jun. 11, 2020).

[184] "Drone Footage Shows Digging of Mass Graves in New York City

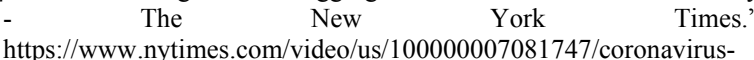
nyc-mass-graves.html (accessed Jun. 11, 2020).

[185] "Kennebecasis Regional Police Force welcomes new aerial drone New Brunswick | Globalnews.ca.' https://globalnews.ca/news/6396021/kennebecasis-police-drone/ (accessed Jun. 09, 2020).

[186] "The Las Vegas Strip Aerial Drone Footage during COVID-19 Pandemic with Empty Streets and No People - YouTube." https://www.youtube.com/watch?v=L8P4kyu6168 (accessed Jun. 11, 2020).

[187] "Arctic Drone Labs - Finnish Drone Expertise." https://www.arcticdronelabs.com/ (accessed Jun. 05, 2020). 